\title{
Effect of Natural Phytogenic Extract Herbs on Physiological Status and Carcass Traits of Broiler Chickens
}

\author{
A. M. Abd El-Hady1, Ghada Mostafa El Ashry ${ }^{2}$, O. A. H. El-Ghalid1 \\ ${ }^{1}$ Poultry Production Department, Faculty of Agriculture, Alexandria University, Alexandria, Egypt \\ ${ }^{2}$ Regional Centre for Food and Feed, Agriculture Research Centre, Ministry of Agriculture, Dokki, Giza, Egypt \\ Email: *ghadaashry@yahoo.com
}

How to cite this paper: El-Hady, A.M.A., El Ashry, G.M. and El-Ghalid, O.A.H. (2020) Effect of Natural Phytogenic Extract Herbs on Physiological Status and Carcass Traits of Broiler Chickens. Open Journal of Animal Sciences, 10, 134-151.

https://doi.org/10.4236/ojas.2020.101007

Received: November 12, 2019

Accepted: January 14, 2020

Published: January 17, 2020

Copyright $\odot 2020$ by author(s) and Scientific Research Publishing Inc. This work is licensed under the Creative Commons Attribution International License (CC BY 4.0).

http://creativecommons.org/licenses/by/4.0/

\begin{abstract}
This paper was conducted to monitor the effect of mixed essential oils $\left(\right.$ AROMIX $^{\circledR}$ ) as phytogenic extract herbs administration in drinking water on growth performance, hematological, biochemical, immunological statuses and carcass traits of broiler chickens. A total number of 240 unsexed broiler chicks (Cobb-500) strain, were randomly divided to four equal groups, 60 chicks each at seven days of age. The first group drank tap water (control), the second, third and fourth group were drank the same water, adding $1 \mathrm{ml}$ AROMIX $^{\circledR}$ per 5, 10 and 15 liter tap water, respectively for 5 week of age. It was cleared from the results that there was a significant improve in feed conversion ratio, red and white blood cell counts, total protein, albumin, globulin, calcium, inorganic phosphorus and a relative reduction in the liver enzymes but in the normal range. However, it was observed that mix essential oils have no significant impact on carcass organs. High levels of the vital parameters, low levels of hepatic enzymes showed that birds health was good and relative improvement in immune system. The relative improvement of the absorption of minerals such as calcium and inorganic phosphorus to the positive role of essential oils. Administration in drank water was occasion, a regular activity of hepatic enzymes which can evidence safety and hepato-protective nature of these oils. Therefore, it is cleared from the results that the addition of these extract herbs in drinking water enhances the health meat, performance and physiological status of broiler chicks, which helps to obtain healthy meat and suitable for human consumption.
\end{abstract}

\section{Keywords}

Essential Oils, Extract Herbs, Performance, Carcass, Immune, Broilers 


\section{Introduction}

Essential oils, a complex mixture of different compounds, extracted from spices and herb composed of aromatic and volatile substances [1]. Thyme and oregano oil contains two main ingredients, carvacrol, and thymol, respectively, and there are some biological properties of essential oils such as they act as antimicrobial, antioxidant, enzymatic, digestion stimulating. Besides these, essential oils also have anti-heat stress effects and they activate the immune system [2]. Phytogenic feed additives, such as essential oils affected on growth rate and improvement of the immune system of animals and birds [3]. The growth performance improved significantly when adding herbal feed additives to the diets of livestock animals and chickens [4]. Some studies have observed that phytogenic plant dietary supplements have positive effects on broiler chickens performance during a coccidial challenge and have identified that a characteristic of essential oils in their antibacterial property has been well tested in vitro for more than once against a large number of pathogenic microorganism, which includes Gram-positive as well as Gram-negative bacteria [5]. The additions of cellular feed phytogenic additive to broilers stimulate intestinal secretion in the mucous membranes, an effect that weakens the adhesion of pathogens and thus plays a prominent role in the stability of useful microbes in the animals gut [6]. These findings support the hypothesis that phytogenic feed additives positively affect intestine functions. Hence the reciprocal study aimed to impact assessment of dietary supplements of different levels of AROMIX ${ }^{\circledR}$ as mix extract herbs on growth performance, hematological, biochemical, immunological and carcass characteristics in broiler.

\section{Materials and Methods}

This study was executed during the winter season (January and February 2017) at the Poultry Research Center, Poultry Production Department, Faculty of Agriculture, Alexandria University, Egypt.

All animal care procedures were approved by Institutional Animal Care and Use Committee in Alexandria University, with review report number AU08190319321.

\subsection{AROMIX ${ }^{\circledR}$ Composition}

AROMIX $^{\circledR}$ is a new blend of natural herbs and seasoned spices with fine extracts. Approving to regulation 2336/2016 to administration in drinking water for use in poultry production, flavor scan be classified as sensory additions. Therefore, AROMIX ${ }^{\circledR \circledast}$ as phytogenic extract herbs were known as a flavor for poultry production and it carried out in accordance with appropriate regulations developed by the Agriculture Research Center (ARC) of the Animal Production Research Institute. AROMIX ${ }^{\circledR} 2336$, Masa Egypt for import and export, Smouha, Alexandria, Egypt. For determination of active chemical constituents, about 100 
Table 1. AROMIX ${ }^{\circledR}$ ingredients.

\begin{tabular}{|c|c|c|c|c|c|c|c|}
\hline Ser. & Ingredient Name & Ret.(Min.) & Chemical Formula & Imperical Form. & Mol. Wt. & Wt\% oil & \%Ingrediant \\
\hline \multirow[t]{2}{*}{1} & Carvacrol & 10.492 & $\left(\mathrm{CH}_{3}\right)_{2}-\mathrm{CH}-\mathrm{C}_{6} \mathrm{H}_{3}-\mathrm{CH}_{3}(-\mathrm{OH})$ & $\mathrm{C}_{10} \mathrm{H}_{14} \mathrm{O}$ & 150 & 4 & 3.6 \\
\hline & Hydroxy Cumene & & & & & & \\
\hline \multirow[t]{2}{*}{2} & Levo menthol & 8.481 & $\left(\mathrm{CH}_{3}\right)_{2}-\mathrm{CH}-\mathrm{C}_{6} \mathrm{H}_{3}-\mathrm{CH}_{3}(-\mathrm{OH})$ & $\mathrm{C}_{10} \mathrm{H}_{20} \mathrm{O}$ & 156 & 3.3 & 1.1 \\
\hline & Isomenthol & & & & & & \\
\hline 3 & $\mathrm{o}, \mathrm{m}, \mathrm{p}$-Cymene & 5.689 & $\left(\mathrm{CH}_{3}\right)_{2}-\mathrm{CH}-\mathrm{C}_{6} \mathrm{H}_{4}-\left(\mathrm{CH}_{3}\right)$ & $\mathrm{C} 10 \mathrm{H} 14$ & 134 & 1.7 & 0.27 \\
\hline \multirow[t]{2}{*}{4} & p-Menthone & 7.872 & $\left(\mathrm{CH}_{3}\right)_{2}-\mathrm{CH}-\mathrm{C}_{6} \mathrm{H}_{8}=\mathrm{O}$ & $\mathrm{C} 10 \mathrm{H} 18 \mathrm{O}$ & 154 & 1.7 & 0.22 \\
\hline & Iso, Trans-Menthone & & & & & & \\
\hline
\end{tabular}

$\mathrm{ml}$ AROMIX $^{\circledR}$ were soaked in $150 \mathrm{~mL}$ of methanol, acetone, and hexane solvent $(1: 1: 1 \mathrm{v} / \mathrm{v}$; HPLC grad) at room temperature. After $24 \mathrm{~h}$ of soaking, extract was filtered through Whatmann No.1 and over active charcoal to remove chlorophyll. Extract was concentrated to $20 \mathrm{~mL}$ and then lyophilized with a freeze dryer (Alpha 1 - 4 L Dplus, Martin Christ, Osterode am Harz, Germany) to obtain dried extract [7]. Exactly $10 \mathrm{~mL}$ from the extract was analyzed using GC-MS [Thermo Scientific, Trace GC Ultra/ISQ Single Quadrupole MS, TG-5MS fused silica capillary column (30 m long, $0.25 \mathrm{~mm}$ internal diameter, and $0.1 \mathrm{~mm}$ film thickness)]. For GC-MS detection, an electron ionization system with ionization energy of 70 electron volts $(\mathrm{eV})$ was used, and Helium was used as the carrier gas at a constant flow rate of $1 \mathrm{ml} / \mathrm{min}$. Injector and MS transfer line temperature was set at $280^{\circ} \mathrm{C}$. Quantification of all the identified components was investigated using a percent relative peak area. A tentative identification of the compounds was performed based on the comparison of their relative retention time and mass spectra with those of the NIST, WILLY library data of the GC-MS system. AROMIX ${ }^{\circledR}$, which contained active components: Carvacrol Hydroxy Cumene 3.6\%, Levo menthol Iso-menthol 1.1\%, O, M, P-Cymene M-Isopropyl toluene $0.27 \%$ and P-MenthoneIso, Trans-Menthone $0.22 \%$ Table 1 .

\subsection{Experimental Design}

A total number of 240 unsexed (Cobb-500) broiler chicks, aged 7 days. Four experimental groups were randomly assigned to each group containing 60 chicks. Each group was divided into 3 replicates each with 20 chicks. Chicks were housed in breeding pens with fresh wood shavings; gas heater was used to provide the chicks with heat needed for brooding, in an open system that is well 
ventilated and kept under the same administrative, health and environmental conditions. Broiler chickens of the $2^{\text {nd }}, 3^{\text {rd }}$ and $4^{\text {th }}$ group chicks were given $1 \mathrm{ml}$ AROMIX $^{\circledR}$ per 5, 10 and 15 liter tap water throughout the experiment period from 7 to 35 days of age. The first group was used as a control, treated the same way except that chicks were given tap water only. The feeding trial in Table 2 was extended for 5 weeks of age. Experimental diets were formulated to be isocaloric, isonitrogenous which provide chicks during starter from the first day to two weeks of age, a grower from two to four weeks of age and finisher at the last week until 35 days of age [8]. Chicks were fed the commercial basal diets ad libitum throughout the trial period ( 1 - 35 days of age).

\subsection{Equipment and Working Procedures}

The chemical analysis of mixed extract herbs $\left(\mathrm{AROMIX}^{\circledR}\right)$ as phytogenic component

Table 2. Composition and chemical analysis of basal and experimental diets.

\begin{tabular}{|c|c|c|c|}
\hline Ingredients, $\%$ & Starter & Grower & Finisher \\
\hline Yellow corn & 56.20 & 58.40 & 62.90 \\
\hline Soybean meal (46\%) & 29.30 & 27.30 & 23.32 \\
\hline Corn gluten meal (60\%) & 7.82 & 6.40 & 6.00 \\
\hline Soybean oil & 2.40 & 3.80 & 3.40 \\
\hline Di-calcium phosphate & 1.76 & 1.84 & 1.55 \\
\hline Lime stone & 1.30 & 1.10 & 1.76 \\
\hline L-lysine HCL & 0.40 & 0.31 & 0.27 \\
\hline DL-methionine & 0.13 & 0.16 & 0.09 \\
\hline Salt (Nacl) & 0.35 & 0.35 & 0.35 \\
\hline Sodium bicarbonate & 0.04 & 0.04 & 0.06 \\
\hline Broiler premix ${ }^{*}$ & 0.30 & 0.30 & 0.30 \\
\hline Total & 100 & 100 & 100 \\
\hline \multicolumn{4}{|c|}{ Calculated analysis: } \\
\hline Crude protein, $\%$ & 22.6 & 21.1 & 19.2 \\
\hline $\mathrm{ME}, \mathrm{kcal} / \mathrm{kg}$ & 3063 & 3129 & 3149 \\
\hline Ether extract, \% & 6.21 & 5.65 & 7.12 \\
\hline Calcium, \% & 1.02 & 1.02 & 0.99 \\
\hline Phosphorus available, \% & 0.48 & 0.51 & 0.45 \\
\hline Methionine, \% & 0.54 & 0.54 & 0.48 \\
\hline Lysine, \% & 1.32 & 1.28 & 1.12 \\
\hline Methionine + Cysteine, $\%$ & 0.95 & 0.88 & 0.84 \\
\hline
\end{tabular}

*Each kg of Vitamins and Mineral Mixtures contained: 12000 I.U Vit. (A); 2000 I.U Vit. (D3); 10 mg Vit. (E); 2 mg Vit. (K3); 1 mg Vit. (B1); 5 mg Vit. (B2); 1.5 mgVit. (B6); $10 \mu \mathrm{gVit}$. (B12); 50 g Biotin; $10 \mathrm{mg}$ Pantothenic acid; $30 \mathrm{mg}$ Niacin; $1 \mathrm{mg}$ Folic acid; $60 \mathrm{mg}$ Manganese; $50 \mathrm{mg}$ Zinc; $30 \mathrm{mg}$ Iron; $10 \mathrm{mg}$ Copper; $1 \mathrm{mg}$ Iodine; $0.1 \mathrm{mg}$ Selenium and $0.1 \mathrm{mg}$ Cobalt (NRC, 1994). 
was carried out with Infrared spectra. The $\mathrm{KBr}$ IR spectra have been recorded using the Perkin-Elmer spectrophotometer model 1430 which covers the frequency range $200-4000 \mathrm{~cm}^{-1}$. The instrument was situated at the Institute of High Graduate Studies and Research, Alexandria University, Egypt. Results from these analyses are shown in Figure 1. The spectra of peppermint (Menthol) is very different than spectra of mixture, the signals presented at 2966, $2922 \mathrm{~cm}^{-1}$ stretching vibration of $\mathrm{C}-\mathrm{H}$ bond $1773 \mathrm{~cm}^{-1} \mathrm{~cm}^{-1}$ due to $\mathrm{C}=\mathrm{O}, 1456$ and 1372 $\mathrm{cm}^{-1}$ bending $\mathrm{CH}_{2} \mathrm{CH}_{3}$ and bands at $1085,1045 \mathrm{~cm}^{-1}$ due to alkene are the important peaks that may identify Menthol which showed slight shift and appear or disappear some peak at oil mixture indicate that Menthol is the major component of this oil [9].

\subsection{Data Collected}

During the treatment period, from one day to five weeks of age, live body weight (LBW), body weight gain (BWG), feed consumption (FC) and feed conversion ratio (FCR) were recorded individually weekly. Before the slaughter was completed, $3 \mathrm{ml}$ of wing vein blood samples were assembled from the chicks in clean tubes with heparin or without heparin, blood samples were rejected at $4000 \mathrm{rpm}$ for up to 20 minutes and the clear serum was isolated and stocked at $-20^{\circ} \mathrm{C}$ until biochemical analysis. Heparin blood samples were collected and used part of itwas used to assess blood in blood haematological values including the number of red and white blood cells count (RBCs and WBCs), numbers of platelets and their differential count of WBCs, the H/L

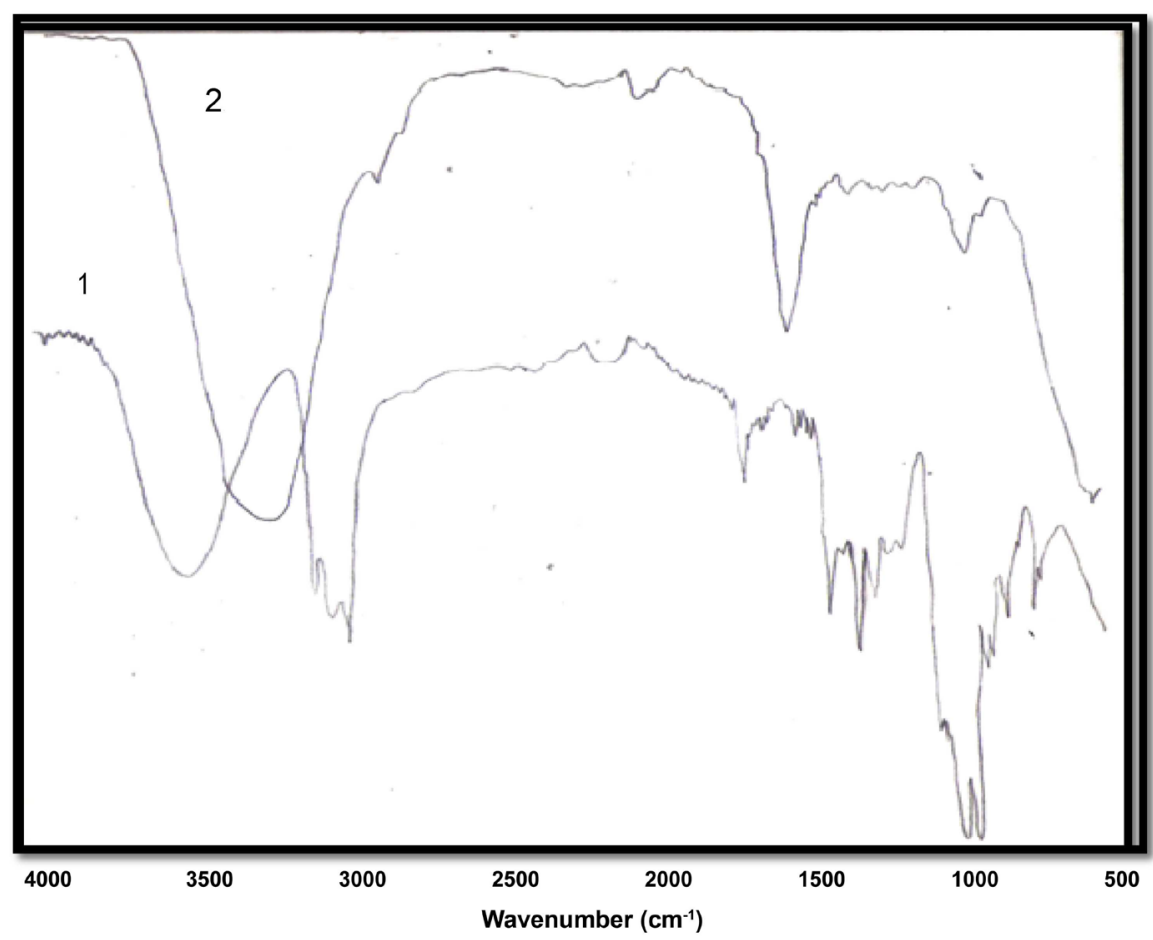

Figure 1. Infrared spectra of 1-menthol (peppermint) and 2-mix essential oil. 
ratio was estimated by dividing the total count of heterophils of the total number of lymphocytes. [10] They noticed that the values of packed corpuscular volume, mean of corpuscular volume, the mean of corpuscular haemoglobin, and the mean of corpuscular haemoglobin concentration (PCV, $\mathrm{MCV}, \mathrm{MCH}$ and $\mathrm{MCHC}$ ), respectively were estimated. All blood biochemical variables were determined calorimetrically using commercials kits. The colorimetric method was used by the commercial group of kits acquired from Reactivos GPL, from Barcelona, Spain to analyzed blood serum for total protein, albumin, total lipids, cholesterol, triglycerides, low and high-density lipoprotein (LDL and HDL, respectively) concentrations. Using the method of subtraction of albumin levels from the corresponding levels of the total protein, in order to calculate the value of serum globulin. By chemical kits of Diagnostic Products Corporation, Los Angeles, USA plasma glucose level, creatinine, uric acid, serum calcium level and the concentrations of inorganic phosphorus were measured. By the calorimetric method, the transaminase enzymes activities were estimated of aspartate andalanine aminotransferase (AST and ALT, respectively) andalkaline phosphatase (ALP). The value of plasma total tri-iodothyronine (T3) was tested using the radioimmunoassay technique by chemical kits of Diagnostic Products Corporation, Los Angeles, USA. Using kits a Reactivos GPL kit, produced in Barcelona, Spain to analyzeserum immunoglobulin (IgG), plasma total antioxidant capacity (TAC) and malondialdehyde (MDA) activity.

\subsection{Slaughter Procedure}

All procedures were including all animal housing, handling, and surgical procedures, was reviewed and approved by the University of Alexandria Institutional Animal Care in Egypt and Use Committee prior to experimentation.

At 35 days of age, six fasted chicks ( 3 male and 3 female) of each group were randomized appropriated, fasted for 10 hours before slaughter at 8:00 am O'clock and individually weighted. After scalding, feather picking and evisceration carcass, organs (liver, kidney, gizzard, heart, pancreas, adrenal, abdominal fat, cecum and intestine) were removed and weighed. Intestine, cecum lengths were measured to the nearest centimeter $(\mathrm{cm})$. Immune organs (spleen, thymus and bursa) were removed and weighed. The length and width of tibia bone were measured to the nearest centimeter $(\mathrm{cm})$ then weighed. Organs were weighed to determine the relative ( $\mathrm{g} / 100 \mathrm{~g}$ live body weight).

\subsection{Statistical Analysis}

The trial was statistically analyzed under a fully randomized design system and the results were tested in a variance analysis method using the general procedure of liner model [11]. The Duncan's test [12] was estimated using differences between means. 


\section{Results and Discussion}

\subsection{Growth Performance}

The results of this experiment towards the goal up to determine the effect of AROMIX $^{\circledR}$ on broiler performance. The research has revealed a series of results to present as follows.

The results of the weekly treatment of broilers with AROMIX ${ }^{\circledR}$ on live body weight (LBW) and body weight gain (BWG) for 5 weeks throughout the experimental period are presented in Table 3 AROMIX $^{\circledR}$ treatments significantly $(P=0.0001)$ increased weekly LBW by 1.66 and $1.32 \%$ of the controls' value with the $1 \mathrm{ml} \mathrm{AROMIX}{ }^{\circledR}$ per 10 and 15 liter treatments, respectively, with the best weekly LBW being at the $1 \mathrm{ml}$ AROMIX $^{\circledR}$ per 10 liter dose (T3). Chick's weekly BWG was increased significantly $(P=0.0001)$ to reach $3.56 \%$ and $3.19 \%$ of control chicks with the $1 \mathrm{ml}$ AROMIX $^{\circledR}$ per 10 and 15 liter treatments, respectively.

It is worthy to notice that the improvement in final LBW and BWG gain which occurred in broiler chickens administrated AROMIX ${ }^{\circledR}$ may be due to the biological functions of the main components of the residual essential oil in AROMIX ${ }^{\circledR}$.

Chick's weekly feed consumption (FC) Table 3 showed a non-significant decrease $(P=0.0548)$ during the total experimental period at 35 days of age. The significant $(P=0.0004)$ improvement in feed conversion ratio (FCR) Table 3 which was improved by 3.59 and $2.99 \%$ compared with control with the $1 \mathrm{ml}$ $\mathrm{AROMIX}^{\circledast}$ per 10 and 15 liter treatments, respectively, may be due to increased body weight gain with reduced feed consumption, with the best feed conversion ratio observed at the (T3) dose.

The enhanced of FCR as an effect of administration of AROMIX ${ }^{\circledR}$ to the tab water could be due to the decrease in FC joined with an increase $(P \leq 0.05)$ in live body weight (LBW).

The results obtained are similar to many other studies by [13] noticed that improvement in the growth performance and the feed intake was similar between groups were addition essential oil mix to a standard diet of broilers. The action of herbal extracts as antioxidants, antibacterial, antifungal and antiprotozoal also adds to the positive improvement in bird's performance. [14] pointed out that the improvement in dietary efficiency with feeding on herbal extracts is associated with improved digestion of protein and increased rate of utilization in the small intestine. The entity of a mixture of essential fatty acids such as linolenic and linoleic acids, in many herbs extracts that are important and necessary for growth may be due to the positive effect of herbs in live body weight and overall performance [15]. Similar results by [16] found that the essential oils mixture (125 ppm containing essential oil of oregano, anise, and citrus peel) was conducted in the diet. Characteristics of essential oils can promote the stimulation of gastrointestinal secretion, circulatory, antioxidant, antimicrobial and the immune status [17]. 
Table 3. Effect of AROMIX ${ }^{\circledR}$ administration compared with control on body weight (BW), body weight gain (BWG), feed consumption (FC) and feed conversion ratio (FCR) measured weekly at age $(1,7,14,21,28$ and $35 \mathrm{~d})(\mathrm{X} \pm \mathrm{SE})$ in broilers (Cobb 500).

\begin{tabular}{|c|c|c|c|c|c|}
\hline \multirow{2}{*}{ Parameter } & \multicolumn{4}{|c|}{ Treatment } & \multirow{2}{*}{ P-Value } \\
\hline & $\mathrm{T} 1$ & $\mathrm{~T} 2$ & T3 & $\mathrm{T} 4$ & \\
\hline BW, day: 1 & $50.93 \pm 3.4$ & $50.78 \pm 2.55$ & $50.03 \pm 2.48$ & $50.31 \pm 5.45$ & 0.1598 \\
\hline 7 & $159.02 \pm 2.90$ & $160.81 \pm 4.57$ & $160.55 \pm 3.59$ & $160.59 \pm 4.45$ & 0.1201 \\
\hline 14 & $363.49 \pm 8.21^{c}$ & $373.65 \pm 3.85^{\mathrm{a}}$ & $368.74 \pm 6.03^{b}$ & $375.29 \pm 4.46^{\mathrm{a}}$ & 0.0001 \\
\hline 21 & $749.01 \pm 6.38^{\mathrm{d}}$ & $798.28 \pm 8.29^{a}$ & $774.65 \pm 7.33^{\mathrm{b}}$ & $758.69 \pm 5.74^{c}$ & 0.0001 \\
\hline 28 & $1223.9 \pm 12.69^{b}$ & $1249.12 \pm 8.25^{\mathrm{a}}$ & $1242.73 \pm 10.45^{\mathrm{a}}$ & $1208.66 \pm 9.35^{b}$ & 0.0001 \\
\hline 35 & $1698.79 \pm 45.78^{b}$ & $1706.94 \pm 38.65^{\mathrm{b}}$ & $1727.00 \pm 31.58^{\mathrm{a}}$ & $1721.20 \pm 39.66^{a}$ & 0.0001 \\
\hline BWG, day: $1-7$ & $108.09 \pm 4.51$ & $110.03 \pm 5.95$ & $110.52 \pm 6.21$ & $110.28 \pm 3.47$ & 0.2452 \\
\hline $7-14$ & $204.48 \pm 9.88^{\mathrm{b}}$ & $212.84 \pm 8.12^{\mathrm{a}}$ & $208.19 \pm 5.48^{\mathrm{ab}}$ & $214.70 \pm 5.61^{\mathrm{a}}$ & 0.0001 \\
\hline $14-21$ & $385.52 \pm 11.37^{\mathrm{c}}$ & $424.63 \pm 17.75^{\mathrm{a}}$ & $405.91 \pm 11.22^{\mathrm{b}}$ & $383.40 \pm 9.41^{\mathrm{c}}$ & 0.0001 \\
\hline $21-28$ & $446.27 \pm 24.57^{\mathrm{b}}$ & $450.84 \pm 20.95^{\mathrm{b}}$ & $468.08 \pm 12.63^{\mathrm{a}}$ & $449.97 \pm 17.26^{\mathrm{b}}$ & 0.0001 \\
\hline $28-35$ & $474.89 \pm 11.33^{\mathrm{b}}$ & $457.81 \pm 20.03^{c}$ & $484.27 \pm 28.10^{\mathrm{b}}$ & $512.54 \pm 21.43^{\mathrm{a}}$ & 0.0001 \\
\hline $1-35$ & $1619.25 \pm 35.58^{c}$ & $1656.16 \pm 29.31^{\mathrm{b}}$ & $1676.97 \pm 26.24^{a}$ & $1670.89 \pm 29.06^{a}$ & 0.0001 \\
\hline FC, day: 1 - 7 & $171.63 \pm 3.69$ & $167.00 \pm 4.86$ & $166.50 \pm 3.78$ & $167.33 \pm 3.27$ & 0.4438 \\
\hline $7-14$ & $337.17 \pm 16.78$ & $334.17 \pm 10.21$ & $334.83 \pm 6.71$ & $331.83 \pm 5.23$ & 0.8463 \\
\hline $14-21$ & $670.33 \pm 17.96$ & $663.67 \pm 11.43$ & $660.00 \pm 13.04$ & $657.33 \pm 8.75$ & 0.4429 \\
\hline $21-28$ & $806.50 \pm 20.85$ & $794.17 \pm 15.63$ & $790.00 \pm 12.65$ & $799.00 \pm 8.94$ & 0.7778 \\
\hline $28-35$ & $821.67 \pm 15.22$ & $813.33 \pm 10.80$ & $812.67 \pm 14.58$ & $803.33 \pm 10.80$ & 0.7970 \\
\hline $1-35$ & $2807.50 \pm 27.15$ & $2772.33 \pm 13.79$ & $2764.00 \pm 15.70$ & $2758.83 \pm 21.53$ & 0.0548 \\
\hline FCR, day: $1-7$ & $1.58 \pm 0.03^{\mathrm{a}}$ & $1.51 \pm 0.02^{\mathrm{b}}$ & $1.51 \pm 0.03^{\mathrm{b}}$ & $1.51 \pm 0.03^{\mathrm{b}}$ & 0.0053 \\
\hline $7-14$ & $1.65 \pm 0.04^{\mathrm{a}}$ & $1.57 \pm 0.03^{\mathrm{b}}$ & $1.61 \pm 0.02^{\mathrm{a}}$ & $1.55 \pm 0.03^{\mathrm{b}}$ & 0.0035 \\
\hline $14-21$ & $1.50 \pm 0.06^{c}$ & $1.56 \pm 0.05^{\mathrm{c}}$ & $1.63 \pm 0.01^{\mathrm{b}}$ & $1.71 \pm 0.01^{\mathrm{a}}$ & 0.0001 \\
\hline $21-28$ & $1.81 \pm 0.06^{\mathrm{a}}$ & $1.76 \pm 0.08^{\mathrm{a}}$ & $1.68 \pm 0.02^{\mathrm{b}}$ & $1.77 \pm 0.02^{\mathrm{a}}$ & 0.0050 \\
\hline $28-35$ & $1.73 \pm 0.10^{\mathrm{b}}$ & $1.77 \pm 0.05^{\mathrm{a}}$ & $1.67 \pm 0.08^{\mathrm{b}}$ & $1.57 \pm 0.05^{c}$ & 0.0001 \\
\hline $1-35$ & $1.67 \pm 0.03^{\mathrm{a}}$ & $1.63 \pm 0.01^{b}$ & $1.61 \pm 0.01^{\mathrm{c}}$ & $1.62 \pm 0.02^{c}$ & 0.0004 \\
\hline
\end{tabular}

a,b,c Means in the same row followed by different letters are significantly different at $P \leq 0.05$. T1 $=$ Control, $\mathrm{T} 2=$ AROMIX $^{\circledR} 1 \mathrm{~cm} / 5$ litter water, T3 $=$ AROMIX $^{\circledR} 1 \mathrm{~cm} / 10$ litter water, $\mathrm{T} 4=$ AROMIX $^{\circledR} 1 \mathrm{~cm} / 15$ litter water.

\subsection{Haematological Parameters}

Haematological parameters are usually related to health status. Data of blood components involving hemoglobin $(\mathrm{Hb})$ value, lymphocyte $(\mathrm{L}) \%$ and platelets count were significantly $(P \leq 0.05)$ higher in broiler chickens of T2, T3 and T4 than T1 Table 4, by (5.44\%; 22.67\%; 23.30\%), (8.86\%; 9.41\%; 7.74\%) and $(31.13 \%$; $33.29 \%$; 41.68\%), respectively. But, red and white blood cells count, packed cell volume, $\mathrm{MCV}, \mathrm{MCH}, \mathrm{MCHC}$, heterophils $(\mathrm{H}), \mathrm{H} / \mathrm{L}$ ratio and monocytes $\%$ were 
Table 4. Effect of AROMIX ${ }^{\circledR}$ administration compared with control on hematological parameters measured at 35 days of age $(\mathrm{X} \pm \mathrm{SE}$ ) in broilers (Cobb 500).

\begin{tabular}{cccccc}
\hline \multirow{2}{*}{ Parameter } & \multicolumn{5}{c}{ Treatment } \\
\cline { 2 - 5 } & T1 & T2 & T3 & T4 & \\
\hline RBC, $10^{6} / \mathrm{ml}$ & $3.88 \pm 0.26$ & $3.93 \pm 0.21$ & $4.27 \pm 0.27$ & $4.39 \pm 0.28$ & 0.3206 \\
Hb, gm/dl & $11.03 \pm 0.63^{\mathrm{b}}$ & $11.63 \pm 0.88^{\mathrm{b}}$ & $13.53 \pm 0.39^{\mathrm{a}}$ & $13.60 \pm 0.36^{\mathrm{a}}$ & 0.0172 \\
PCV, \% & $34.66 \pm 1.19$ & $36.11 \pm 1.88$ & $39.82 \pm 1.22$ & $39.42 \pm 1.97$ & 0.1300 \\
MCV, $\mu m^{3}$ & $91.30 \pm 6.62$ & $93.03 \pm 6.14$ & $95.52 \pm 7.66$ & $91.47 \pm 7.31$ & 0.9516 \\
MCH, pg & $29.21 \pm 2.73$ & $30.07 \pm 2.80$ & $32.40 \pm 2.44$ & $31.74 \pm 2.50$ & 0.7891 \\
MCHC, gm/dl & $31.87 \pm 1.60$ & $32.26 \pm 2.06$ & $34.16 \pm 1.52$ & $34.83 \pm 1.48$ & 0.5765 \\
WBC, 103/ml & $12.91 \pm 0.47$ & $13.50 \pm 0.51$ & $13.98 \pm 0.53$ & $13.75 \pm 0.29$ & 0.4903 \\
Lymphocyte, \% & $60.17 \pm 1.62^{\mathrm{b}}$ & $65.50 \pm 2.66^{\mathrm{a}}$ & $65.83 \pm 1.85^{\mathrm{a}}$ & $64.83 \pm 1.89^{\mathrm{a}}$ & 0.0429 \\
Heterophils, \% & $33.17 \pm 3.25$ & $28.67 \pm 0.76$ & $30.83 \pm 1.62$ & $29.33 \pm 3.27$ & 0.5968 \\
H/L ratio & $0.56 \pm 0.06$ & $0.44 \pm 0.02$ & $0.47 \pm 0.04$ & $0.46 \pm 0.06$ & 0.2897 \\
Monocytes, \% & $5.50 \pm 0.34$ & $5.17 \pm 0.54$ & $6.50 \pm 0.62$ & $6.00 \pm 0.52$ & 0.3840 \\
Platelets, 10 $/ \mathrm{ml}$ & $139.17 \pm 5.13^{\mathrm{b}}$ & $182.50 \pm 10.67^{\mathrm{a}}$ & $185.50 \pm 8.69^{\mathrm{a}}$ & $197.17 \pm 4.39^{\mathrm{a}}$ & 0.0001 \\
\hline
\end{tabular}

a,b,c Means in the same row followed by different letters are significantly different at $P \leq 0.05$. T1 = Control, $\mathrm{T} 2=$ AROMIX $^{\circledR} 1 \mathrm{~cm} / 5$ litter water, $\mathrm{T} 3=$ AROMIX $^{\circledR} 1 \mathrm{~cm} / 10$ litter water, $\mathrm{T} 4=\mathrm{AROMIX}^{\circledR} 1 \mathrm{~cm} / 15$ litter water, RBCs = Red blood cells count; $\mathrm{Hb}=$ hemoglobin; $\mathrm{PCV}=$ packed corpuscular volume; $\mathrm{MCV}=$ mean corpuscular volume; $\mathrm{MCH}=$ mean corpuscular hemoglobin; $\mathrm{MCHC}=$ mean corpuscular hemoglobin concentration; WBCs $=$ white blood cell.

not significantly different in all groups. Improvements in blood components may be due to the addition of AROMIX ${ }^{\circledR}$ due to increased metabolism.

The significant increase in $\mathrm{Hb}$ and platelets values in group T3 and T4 could be explained by the presence of high content of iron in thyme (Thymol as mixed essential oil) which capable of stimulating hemoglobin synthesis and also presence of a variety of important flavonoids with antioxidant activity which responsible for improvement of complete blood count picture. These results corroboration the findings of [18] showed that medicinal plants have a significant effect on blood estimates based on their nutritional status. These values of parameters are given the good result of the physiological profile, pathological status, and nutritional role of animal and have the ability to use to explain the effect of dietary agents and additive supplements in diet. For example, white blood cells when an infection occurs are increased sharply because they are one of the first lines of defense within the body [19]. Feeding broiler chickens on phytogenic plant products had resulted in lower of $\mathrm{H} / \mathrm{L}$ ratio, giving a positive effect of mix essential oils (MEO) on reducing physiological stress in the broiler. The H/L ratio was a biological indicator of pressure in chicken is well documented. In accordance with [20] observed that diet was added with oily extract of thyme and cinnamon increased RBC, HCT, HB and WBC values in broiler chickens.

The reliability of the $\mathrm{H} / \mathrm{L}$ ratio as a biological indicator of stress in broiler was linearly reduced in birds drinking mixed essential oils T2, T3 and T4. The dif- 
ferences were reduced linearly of heterophils to lymphocyte ratio in broilers fed Thymol + Carvacrol, while other values tested, included red and white blood cell (RBC and $\mathrm{WBC}$ ), haemoglobin ( $\mathrm{Hb}$ ) values, and packed cell volume percentage (PCV\%), were not affected by treatment diets and dose therapy [21]. Our findings are comparable with [22] results indicated that the increased in blood haematological components such as PCV, PCV, RBC and WBC in birds fed with the herbal ingredients (ginger, garlic) is a guide of improved oxygen caring capacity of the cells which translated to a better availability of nutrients for utilization to the birds which affecting their wellbeing with an active immune system. Broilers given the extract of Mexican oregano oil (MOO) had slightly increased erythrocytes, haemoglobin and WBC values. The group of control had high values of average corpuscular volume, lymphocytes, monocytes, and the mean of corpuscular haemoglobin, followed by antibiotic therapy group and MOO treatment groups [23].

In contrast, [24] revealed that thyme and ginger indicated favorable influence on the performance of broiler without any impact on RBC, WBC counts, Haemoglobin value and hematocrit percentage.

\subsection{Blood Biochemistry Parameters}

Treatments T2, T3 and T4 noticed significant $(P \leq 0.05)$ increase in serum albumin value when compared with control Table 5 . The increase in the level of serum albumin has been indication of the body animal's retention of protein. Similar results were obtained by [25] higher content of albumin in blood serum may also indicate enhanced nutrient supply, transport and synergic effect of mixed essential oils. The increased level of albumin in group T2, T3 and T4 by $6.25 \%, 11.46 \%$ and $4.51 \%$ than control group are in agreement with the results of [26] who found higher total albumin concentration in broiler fed with ginger powder. These results indicated that the supplement mix of herbal ingredients may non-significant improve globulin level Table 5. These results are in harmony with [27] showed no significant effect in blood serum globulin of broiler chicken feed diet supplemented with garlic extract.

Total lipid and cholesterol levels were significantly $(P=0.0310$ and 0.0001 , respectively) affected by AROMIX ${ }^{\circledR}$ treatments. Total lipid showed a reduction of $7.86 \%, 12.69 \%$ and $8.97 \%$ and cholesterol was reduced by $19.04 \%, 15.34 \%$ and $20.02 \%$ with the three doses of AROMIX ${ }^{\circledR}$, respectively. AROMIX ${ }^{\circledR}$ treatments caused a non-significant reduce in both triglyceride and low-density lipoprotein (LDL) ( $P=0.3011$ and 0.8596 , respectively). Moreover, high-density lipoprotein (HDL) has significantly increased $(P=0.0278)$ to reach $108.30 \%, 123.18 \%$ and $133.19 \%$ of control value with the three groups of AROMIX ${ }^{\circledR}$, respectively. Similarly, [28] reported a decrease in the concentrations of triglyceride and cholesterol in the blood due to the addition of thyme extract or oil in the broiler diet at the level of $200-500 \mathrm{ppm}$. Likewise, [29] found that the dietary supplementation with green tea powder did not effect on cholesterol level of the broiler. 
Table 5. Effect of AROMIX ${ }^{\circledR}$ administration compared with control on blood biochemical parameters measured at 35 days of age $(\mathrm{X} \pm \mathrm{SE})$ in broilers (Cobb 500).

\begin{tabular}{|c|c|c|c|c|c|}
\hline \multirow{2}{*}{ Parameters } & \multicolumn{4}{|c|}{ Treatment } & \multirow{2}{*}{ P-Value } \\
\hline & $\mathrm{T} 1$ & $\mathrm{~T} 2$ & T3 & $\mathrm{T} 4$ & \\
\hline Total protein, g/dl & $5.40 \pm 0.16$ & $5.71 \pm 0.28$ & $5.83 \pm 0.24$ & $5.69 \pm 0.19$ & 0.5614 \\
\hline Albumin, g/dl & $2.88 \pm 0.07^{\mathrm{c}}$ & $3.06 \pm 0.04^{\mathrm{b}}$ & $3.21 \pm 0.05^{\mathrm{a}}$ & $3.01 \pm 0.08^{\mathrm{b}}$ & 0.0001 \\
\hline Globulin, g/dl & $2.52 \pm 0.17$ & $2.65 \pm 0.25$ & $2.62 \pm 0.20$ & $2.68 \pm 0.22$ & 0.9633 \\
\hline Total lipid, mg/dl & $358.50 \pm 9.15^{\mathrm{a}}$ & $330.33 \pm 18.29^{\mathrm{ab}}$ & $313.00 \pm 9.19^{b}$ & $326.33 \pm 9.64^{b}$ & 0.0310 \\
\hline Cholesterol, mg/dl & $153.17 \pm 3.54^{\mathrm{a}}$ & $124.00 \pm 5.85^{\mathrm{b}}$ & $129.67 \pm 4.48^{\mathrm{b}}$ & $122.50 \pm 2.68^{\mathrm{b}}$ & 0.0001 \\
\hline Triglyceride, mg/dl & $72.33 \pm 3.48$ & $64.17 \pm 3.40$ & $67.67 \pm 2.32$ & $68.83 \pm 2.61$ & 0.3011 \\
\hline $\mathrm{LDL}, \mathrm{mg} / \mathrm{dl}$ & $38.10 \pm 2.09$ & $36.25 \pm 1.70$ & $36.67 \pm 2.20$ & $35.50 \pm 2.38$ & 0.8596 \\
\hline $\mathrm{HDL}, \mathrm{mg} / \mathrm{dl}$ & $41.67 \pm 4.35^{\mathrm{b}}$ & $45.13 \pm 3.14^{\mathrm{ab}}$ & $51.33 \pm 6.48^{\mathrm{ab}}$ & $55.50 \pm 5.30^{\mathrm{a}}$ & 0.0278 \\
\hline Glucose, mg/dl & $233.00 \pm 9.19^{a}$ & $222.33 \pm 19.03^{a}$ & $212.33 \pm 6.23^{\mathrm{ab}}$ & $198.00 \pm 6.83^{\mathrm{b}}$ & 0.0389 \\
\hline Creatinine, $\mathrm{mg} / \mathrm{dl}$ & $0.77 \pm 0.04$ & $0.75 \pm 0.03$ & $0.71 \pm 0.03$ & $0.69 \pm 0.03$ & 0.3896 \\
\hline Uric acid, mg/dl & $7.19 \pm 0.67$ & $6.97 \pm 0.38$ & $5.87 \pm 0.23$ & $6.37 \pm 0.26$ & 0.1405 \\
\hline $\mathrm{AST}, \mathrm{U} / \mathrm{L}$ & $50.40 \pm 1.84^{\mathrm{a}}$ & $45.43 \pm 0.47^{\mathrm{b}}$ & $46.23 \pm 0.99^{\mathrm{b}}$ & $47.57 \pm 1.06^{\mathrm{ab}}$ & 0.0253 \\
\hline $\mathrm{ALT}, \mathrm{U} / \mathrm{L}$ & $23.43 \pm 0.73^{\mathrm{a}}$ & $19.85 \pm 0.40^{\mathrm{b}}$ & $18.92 \pm 0.55^{\mathrm{b}}$ & $20.35 \pm 0.51^{\mathrm{b}}$ & 0.0007 \\
\hline ALP, IU/L & $315.83 \pm 15.09$ & $313.22 \pm 13.53$ & $322.73 \pm 12.06$ & $323.81 \pm 4.36$ & 0.9179 \\
\hline $\mathrm{Ca}, \mathrm{mg} / \mathrm{dl}$ & $10.93 \pm 0.23^{b}$ & $11.15 \pm 0.13^{\mathrm{ab}}$ & $11.48 \pm 0.07^{\mathrm{a}}$ & $11.11 \pm 0.07^{\mathrm{ab}}$ & 0.0470 \\
\hline IP, mg/dl & $5.65 \pm 0.12^{\mathrm{b}}$ & $5.92 \pm 0.13^{\mathrm{ab}}$ & $5.84 \pm 0.19^{\mathrm{ab}}$ & $6.06 \pm 0.04^{\mathrm{a}}$ & 0.0479 \\
\hline $\mathrm{T}_{3}, \mathrm{ng} / \mathrm{ml}$ & $2.52 \pm 0.06^{\mathrm{b}}$ & $2.69 \pm 0.06^{\mathrm{b}}$ & $3.01 \pm 0.23^{\mathrm{a}}$ & $3.06 \pm 0.11^{\mathrm{a}}$ & 0.0001 \\
\hline IgG, mg/dl & $34.32 \pm 1.49^{c}$ & $45.54 \pm 2.29^{b}$ & $53.32 \pm 2.37^{\mathrm{a}}$ & $50.48 \pm 2.07^{\mathrm{a}}$ & 0.0001 \\
\hline $\mathrm{TAC}, \mathrm{mM} / \mathrm{L}$ & $1.11 \pm 0.07^{\mathrm{b}}$ & $1.23 \pm 0.10^{\mathrm{ab}}$ & $1.35 \pm 0.02^{\mathrm{a}}$ & $1.42 \pm 0.05^{\mathrm{a}}$ & 0.0409 \\
\hline MDA, IU/L & $137.58 \pm 5.12^{\mathrm{a}}$ & $135.09 \pm 3.23^{\mathrm{ab}}$ & $124.02 \pm 3.63^{\mathrm{b}}$ & $123.83 \pm 2.94^{\mathrm{b}}$ & 0.0512 \\
\hline
\end{tabular}

a,b,c Means in the same row followed by different letters are significantly different at $P \leq 0.05$. T1 $=$ Control, $\mathrm{T} 2=\mathrm{AROMIX}^{\circledR} 1 \mathrm{~cm} / 5$ litter water, T3 $=$ AROMIX $^{\circledR} 1 \mathrm{~cm} / 10$ litter water, $\mathrm{T} 4=\mathrm{AROMIX}^{\circledR} 1 \mathrm{~cm} / 15$ litter water, $\mathrm{LDL}=$ low-density lipoprotein; $\mathrm{HDL}=$ high-density lipoprotein; $\mathrm{AST}=$ aspartate amino transferase; $\mathrm{ALT}=$ alanine amino transferase; $\mathrm{Ca}=$ calcium; $\mathrm{IP}=$ inorganic phosphorus; $\mathrm{T} 3$ = thyroid hormone; $\mathrm{IgG}=$ immunoglobulin $\mathrm{G} ; \mathrm{TAC}=$ total antioxidant capacity and $\mathrm{MDA}=$ malondialdehyde activity.

There was a marked decrease in cholesterol concentration $(P \leq 0.05)$ by $9.64 \%$, $5.25 \%$ and $5.40 \%$ in broilers were under anise, thyme or anise and thyme respectively when compared with control chicks. The reduced plasma content of cholesterol value and LDL may affect the properties of deficient LDL attributed to the deionized portion of leaves rich in fibrous percentage and possibly inhibit absorption of intestinal cholesterol.

Glucose levels decreased significantly $(P=0.0384)$ to reach $4.58 \%, 8.87 \%$ and $15.02 \%$ of the three doses of AROMIX ${ }^{\circledR}$, respectively. The results are consistent with the results of [30] who mentioned that comparative blood biochemical parameters of diet birds were received with a combination of essential oils from the micro-organism, aniseed and acidic fruits. The data of control showed that the acidic fruit had a slightly lower level of glucose $(-4.11 \%)$, a substance found in 
animals directly, it was a substance that indirectly oxidizing animals to save energy.

Although without significance results ( $P=0.0151$ and 0.0494 , respectively), AROMIX $^{\circledR}$ groups decreased creatinine and uric acid concentrations in control with the three doses of AROMIX ${ }^{\circledR}$, respectively. The results indicated an improvement of renal function in blood purification especially with high blood proteins noted in this research with MEO treatments. Results are similar to data [23] who found that treating Arbor Acres broiler with various levels (0.5\%, 1.0\% and 2.0\%) of rosemary and rosemary oil reduced serum creatinine levels.

AST and ALT levels were decreased significantly $(P=0.0253$ and 0.0007 , respectively) affected by AROMIX ${ }^{\circledR}$ treatments. AST noted a reduction of $9.86 \%$, $8.27 \%$ and $5.62 \%$ and ALT was reduced by $15.28 \%, 19.25 \%$ and $13.15 \%$ in comparison with the control, respectively, revealing a slight improvement in liver function. The levels of ALT and AST probably given evidence of liver protection against hepatic degeneration. The low activity for plasma enzymes ALT and AST was registered for individuals fed diets added to the additions with Phy to additive until the treatment did not negatively change the activity of the hepatic enzyme activity [31]. Moreover, alkaline phosphatase (ALP) dedicated a non-significant effect $(P=0.9179)$ in broilers that received mix essential oils $\left(\right.$ AROMIX $\left.^{\circledR}\right)$ in groups T2, T3 and T4 than in the control chicken group.

Treatment with different levels of AROMIX ${ }^{\circledR}$ significantly $(P \leq 0.05)$ increased the proportion of calcium (Ca) and inorganic phosphorus (IP) to maintain a fixed ratio ( $P=0.0470$, and 0.0479 , respectively). The increase was by $2.01 \%$, $5.03 \%$ and $1.65 \%$ in calcium and was by $4.78 \%, 3.36 \%$ and $7.26 \%$ in phosphorous with the three AROMIX ${ }^{\circledR}$ doses, respectively. The increase in serum of Ca and IP levels can be attributed to the increase in the length of the intestine, which increases the uptake of these minerals from the small intestine to the bloodstream, thus promoting the utilization of $\mathrm{Ca}$ and IP, this results are with harmony of [32] a significant increase was observed in serum content of Ca after the supplementation of herbal oils (Thymus vulgaris and Foeniculum vulgare) resembled with the control group. Also, blood calcium concentration increased with the supplemented of flaxseed oil into diets of layers in both experimental groups compared to control group [33].

T3 levels increased significantly $(P=0.0001)$ to reach $106.75,119.44$, and $121.43 \%$ of control chicks with the three doses of AROMIX ${ }^{\circledR}$, respectively. Thyroid hormones play an important role in regulating the metabolism of most of the body's tissues, including important organs such as liver, kidneys, heart and skeletal muscles. It is also known that thyroid hormones work to increase the speed of metabolism and oxidative status by causing an increase in the mitochondrial mass rate, as well as cytochrome content and respiratory rate. The used of AROMIX ${ }^{\circledR}$ compound had helped to improve the blood components and may be due to the increased metabolic cycle.

IgG level was significantly $(P=0.0001)$ affected by AROMIX ${ }^{\circledR}$ treatments. IgG 
concentration was increased of $32.69 \%, 55.36 \%$ and $47.09 \%$ with the different doses of AROMIX ${ }^{\circledR}$, respectively, this shows an improvement of immunity characteristics in blood exceptionally with the exalted haematological parameters (lymphocyte) noted in this research with AROMIX ${ }^{\circledR}$ groups.

These results are agreed with [34] noticed there is a significant increase in the antibody titer versus Newcastle broiler disease as a result of the addition of thyme extract at $500 \mathrm{ppm}$ in drinking water or in feed composition, respectively. Moreover, incorporation of plant extract blend in the broiler feed increased antibody titer and may be attributed to the immunosuppressant and antioxidant properties of the herbal extracts used in the mixture, polyphenol matter noticed in the plant extract have the ability to scavenge free radical and maintain integrity of the structure immune cells [35].

MEO treatments significantly $(P=0.0509)$ increased total antioxidant capacity (TAC) by $10.81 \%, 21.62 \%$ and $27.93 \%$ with different doses, respectively. Differ trend was showed with malondialdehyde (MDA) $(P=0.0512)$ as they were reduced by $1.81 \%, 9.86 \%$ and $9.99 \%$ with different doses of AROMIX ${ }^{\circledR}$, respectively. These results are confirmed by the results of [36] noted that there was a significant decrease in plasma concentration of malondialdehyde (MDA) compared with control group by feeding broiler chickens with $0.1 \%$ of essential oil. Feeding broiler chickens with the addition of Thymol + Carvacrol increased antioxidant enzyme activity that enhanced digestive enzyme activities and immune response, a decreased lipid oxidation of broiler chickens [19]. Also, [37] who stated that dietary supplements of vitamin E, ginger root powder or essential oils (EO) administration to chicks reduced serum MDA concentrations and increased total antioxidant capacity (TAC) compared with control group.

\subsection{Carcass Traits}

The relative weight of the carcass, dressing, liver, kidney, gizzard, adrenal, pancreas, abdominal fat and cecum length were not affected by dietary treatments with AROMIX ${ }^{\circledR}$ (mix essential oils). Results of slaughter carcass traits presented in Table 6 showed that broiler chickens of AROMIX ${ }^{\circledR}$ had significantly higher weight percentages of heart, cecum, intestine and intestine length. Our findings are consistent with [38] observed there were no differences in the weights of gizzard, liver and pancreas of broiler chickens fed on a diet including essential oil herbal extract. Also, [39] pointed out that the addition of thyme and essential oil of black seed in quail diet increased the weight and the length of the intestine.

The relative weight of immune organs like (spleen, thymus and bursa of Fabricius) and tibia characteristics (tibia \% and tibia length) were not affected in birds drinking water with the mix essential oils, while, tibia width was significantly $(P=0.0222)$ affected by AROMIX ${ }^{\circledR}$ treatments. Tibia width was increased of $5.13 \%, 12.82 \%$ and $6.41 \%$ with different doses of AROMIX ${ }^{\circledR}$, respectively. Although without reaching significance $(P=0.0801)$, AROMIX ${ }^{\circledR}$ treatments increased tibia length, these results have indicated that it may be mix essential oils 
Table 6. Effect of AROMIX ${ }^{\circledR}$ administration compared with control on slaughter traits measured at 35 days of age $(\mathrm{X} \pm \mathrm{SE})$ in broilers (Cobb 500).

\begin{tabular}{|c|c|c|c|c|c|}
\hline \multirow{2}{*}{ Parameters } & \multicolumn{4}{|c|}{ Treatment } & \multirow{2}{*}{$P$-Value } \\
\hline & $\mathrm{T} 1$ & $\mathrm{~T} 2$ & T3 & $\mathrm{T} 4$ & \\
\hline \multicolumn{6}{|c|}{ Carcass characteristics } \\
\hline Pre-slaughter, gm & $1671.0 \pm 23.8$ & $1679.0 \pm 19.1$ & $1696.0 \pm 18.8$ & $1690.5 \pm 32.7$ & 0.8742 \\
\hline Carcass, \% & $70.58 \pm 1.60$ & $70.76 \pm 1.76$ & $71.01 \pm 0.65$ & $71.08 \pm 0.75$ & 0.9516 \\
\hline Dressing, \% & $75.09 \pm 1.64$ & $75.47 \pm 1.71$ & $75.86 \pm 0.59$ & $75.95 \pm 0.80$ & 0.8098 \\
\hline Liver, $\%$ & $2.33 \pm 0.12$ & $2.38 \pm 0.05$ & $2.47 \pm 0.08$ & $2.50 \pm 0.08$ & 0.2177 \\
\hline Kidney, \% & $0.66 \pm 0.02$ & $0.71 \pm 0.05$ & $0.68 \pm 0.04$ & $0.70 \pm 0.01$ & 0.0829 \\
\hline Gizzard, \% & $1.61 \pm 0.07$ & $1.63 \pm 0.08$ & $1.71 \pm 0.04$ & $1.70 \pm 0.08$ & 0.3544 \\
\hline Heart, \% & $0.48 \pm 0.02^{\mathrm{c}}$ & $0.57 \pm 0.04^{\mathrm{a}}$ & $0.54 \pm 0.05^{\mathrm{b}}$ & $0.54 \pm 0.01^{\mathrm{b}}$ & 0.0001 \\
\hline Pancreas, \% & $0.26 \pm 0.05$ & $0.27 \pm 0.02$ & $0.27 \pm 0.03$ & $0.26 \pm 0.02$ & 0.9792 \\
\hline Adrenal, $\%$ & $0.007 \pm 0.002$ & $0.008 \pm 0.004$ & $0.009 \pm 0.005$ & $0.009 \pm 0.002$ & 0.2062 \\
\hline Abdominal fat, $\%$ & $1.26 \pm 0.09$ & $1.10 \pm 0.17$ & $1.18 \pm 0.09$ & $1.04 \pm 0.03$ & 0.5171 \\
\hline Cecum length, $\mathrm{cm}$ & $25.20 \pm 1.75$ & $26.72 \pm 1.58$ & $26.10 \pm 1.34$ & $26.00 \pm 1.27$ & 0.7722 \\
\hline Cecum, \% & $0.80 \pm 0.02^{c}$ & $0.95 \pm 0.06^{\mathrm{b}}$ & $1.04 \pm 0.05^{\mathrm{a}}$ & $0.90 \pm 0.04^{\mathrm{b}}$ & 0.0001 \\
\hline Intestine length, $\mathrm{cm}$ & $185.2 \pm 6.09^{c}$ & $191.6 \pm 6.95 b^{c}$ & $194.0 \pm 7.40^{\mathrm{a}}$ & $192.40 \pm 4.48^{\mathrm{ab}}$ & 0.0049 \\
\hline Intestine, $\%$ & $5.34 \pm 0.22^{c}$ & $5.78 \pm 0.19^{\mathrm{b}}$ & $6.12 \pm 0.28^{\mathrm{a}}$ & $5.44 \pm 0.10^{c}$ & 0.0004 \\
\hline \multicolumn{6}{|c|}{ Immune organs } \\
\hline Spleen, \% & $0.10 \pm 0.01$ & $0.14 \pm 0.02$ & $0.13 \pm 0.04$ & $0.13 \pm 0.01$ & 0.0629 \\
\hline Thymus, $\%$ & $0.231 \pm 0.002$ & $0.237 \pm 0.005$ & $0.338 \pm 0.003$ & $0.235 \pm 0.002$ & 0.0518 \\
\hline Bursa, \% & $0.08 \pm 0.01$ & $0.07 \pm 0.01$ & $0.10 \pm 0.02$ & $0.08 \pm 0.01$ & 0.0721 \\
\hline \multicolumn{6}{|c|}{ Tibia characteristics } \\
\hline Tibia, \% & $0.76 \pm 0.03$ & $0.78 \pm 0.04$ & $0.85 \pm 0.04$ & $0.77 \pm 0.02$ & 0.0785 \\
\hline Tibia length, $\mathrm{cm}$ & $9.02 \pm 0.05^{\mathrm{b}}$ & $9.27 \pm 0.04^{\mathrm{a}}$ & $9.27 \pm 0.12^{\mathrm{a}}$ & $9.12 \pm 0.14^{\mathrm{c}}$ & 0.0401 \\
\hline Tibia width, $\mathrm{cm}$ & $0.78 \pm 0.03^{\mathrm{b}}$ & $0.82 \pm 0.05^{\mathrm{b}}$ & $0.88 \pm 0.08^{\mathrm{a}}$ & $0.83 \pm 0.03^{\mathrm{ab}}$ & 0.0222 \\
\hline
\end{tabular}

a,b,c Means in the same row followed by different letters are significantly different at $P \leq 0.05$. T1 = Control, $\mathrm{T} 2=\mathrm{AROMIX}^{\circledR} 1 \mathrm{~cm} / 5$ litter water, T3 $=$ AROMIX $^{\circledR} 1 \mathrm{~cm} / 10$ litter water, $\mathrm{T} 4=\mathrm{AROMIX}^{\circledR} 1 \mathrm{~cm} / 15$ litter water.

have improved of $\mathrm{Ca}$ metabolism and consequently increased the tibia length by hyperplasia and hypertrophy of osteoclast cells and these results need more investigation on the bone by histology examination.

These data support the findings of [40] who showed that there were no differences in the weight of the spleen and Fabricius bursa of live body weight in the diet broiler containing the phytogenic compound. This finding is consistent with the results of [41] suggested that thyme and ginger oils did not result in any significant changes in the relative weights of these lymphoid organs in all treatments. Also, [42] showed that chicken feeding at different levels of probiotics or pungent substance as natural feed additive did not effect on (tibia weight, length, 
width and tibia seeder index) as bone measurements.

\section{Conclusion and Application}

The results can be summarized in the fact that the addition of AROMIX $^{\circledR}$ as mix extract herbs in drinking water for broiler chickens helped for improvement physiological characteristics as well as an enhanced production performance by achieving the highest rate of body weight gain and feed conversion. Furthermore, enhanced hematological values and had a positive effect on liver and kidney functions and increased utilization of feed minerals. Thus, high metabolic functions can be predicted by increasing T3 levels and improving the oxidative state. The addition of these herbs enhances the health meat, of broiler chicks, which helps to obtain healthy meat and is suitable for human consumption.

\section{Acknowledgements}

The authors wish to thank the Poultry Research Center of the Poultry Production Department, Faculty of Agriculture (El-Shatby), Alexandria University, Egypt for helping in providing the chickens and supervising the experiment. The authors gratefully acknowledge all participating research assistants and laboratory technicians for their technical and scientific researchers.

\section{Conflicts of Interest}

The authors declare no conflicts of interest regarding the publication of this paper.

\section{References}

[1] Alçiçek, A., Bozkurt, M. and Çabuk, M. (2003) The Effects of an Essential Oil Combination Derived from Selected Herbs Growing Wild in Turkey on Broiler Performance. South African Journal of Animal Science, 33, 89-94. https://doi.org/10.4314/sajas.v33i2.3761

[2] Ilias, G., Eleftherios, B., fterpi, C.E. and Panagiota, F. (2018) A Feed Additive with Functional Properties. In: Holban, A.M. and Grumezescu, A.M., Eds., Therapeutic Foods. A Volume in Handbook of Food Bioengineering, Elsevier, Amsterdam, 179-208. https://doi.org/10.1016/B978-0-12-811517-6.00006-4

[3] Botsoglou, N.A., Florou-Paneri, P., Christaki, E., Fletouris, D.J. and Spais, A.B. (2002) Effect of Dietary Oregano Essential Oil on Performance of Chickens and on Iron-Induced Lipid Oxidation of Breast, Thigh and Abdominal Fat Tissues. British Poultry Science, 43, 223-230. https://doi.org/10.1080/00071660120121436

[4] Abd El-Hady, A.M., El-Ghalid, O.A.H. and EL-Raffa, A.M. (2013) Influence of a Herbal Feed Additives (Digestarom) on Productive Performance and Blood Constituents of Growing Rabbits. Egyptian Journal Animal Production, 50, 27-37.

[5] Upadhyaya, I., Upadhyay, A., Kollanoor-Johny, A., Darre, M.J. and Venkitanarayanan, K. (2013) Effect of Plant Derived Antimicrobials on Salmonella Enteritidis Adhesion to and Invasion of Primary Chicken Oviduct Epithelial Cells in Vitro and Virulence Gene Expression. International Journal of Molecular Sciences, 14, 608-625. https://doi.org/10.3390/ijms140510608 
[6] Jamroz, D., Wiliczkiewicz, A., Werteleckı, T., Orda, J. and Sukorupinska, J. (2005) Use of Active Substances of Plant Origin in Chicken Diets Based on Maize and Locally Grown Cereals. British Poultry Science, 46, 485-493. https://doi.org/10.1080/00071660500191056

[7] Kholif, A.E., Gouda, G.A., Anele, U.Y. and Galyean, M.L. (2018) Extract of Moringa oleifera Leaves Improves Feed Utilization of Lactating Nubian Goats. Small Ruminant Research, 158, 69-75. https://doi.org/10.1016/j.smallrumres.2017.10.014

[8] Morsy, T.A., Kholif, A.E., Matloup, H.O., Abu Elella, A., Anele, U.Y. and Caton, J.S. (2018) Mustard and Cumin Seeds Improve Feed Utilization, Milk Production and Milk Fatty Acids of Damascus Goats. Journal of Dairy Research, 85, 142-151. https://doi.org/10.1017/S0022029918000043

[9] Stephanie, J.S., Fabie-agapin, J., Jay, M., Danilo, O. and Vivian, A.T. (2017) Physico-Chemical Characterization of Essential Oil from the Peel and Leaf of Dalanghita (Citrus Nobilis). International Journal of Novel Research in Physics Chemistry and Mathematics, 4, 1-13.

[10] Feldman, B.F., Zinkl, J.G. and Jain, N.E. (2000) Schalm's Veterinary Haematology. Lippincott Williams and Wilkins, Philadelphia.

[11] SAS (1999) Statistical Analysis System (SAS) User's Guide: Statistics. SAS Institute, Inc., Carry.

[12] Duncan, D.B. (1955) Multiple Range and Multiple F Tests. Biometrics, 11, 1-42. https://doi.org/10.2307/3001478

[13] Cross, D.E., Mc, R.M., Devitt, K., Hillman, K. and Acamovic, T. (2007) The Effect of Herbs and Their Associated Essential Oils on Performance, Dietary Digestibility and Gut Microflora in Chickens from 7 to 28 Days of Age. British Poultry Science, 48, 496-506. https://doi.org/10.1080/00071660701463221

[14] Peric, L., Milosevic, N., Zikic, D., Bjedov, S., Cvetkovic, D., Markov, S. and Steiner, T. (2010) Effects of Probiotic and Phytogenic Products on Performance, Gut Morphology and Cecal Microflora of Broiler Chickens. Archiv fur Tierzucht, 53, 350-359. https://doi.org/10.5194/aab-53-350-2010

[15] Mountzouris, K., Paraskeyas, C.V., Tsirtsikos, P., Palamidi, I., Steiner, T., Schatzmayr, G. and Fegeros, K. (2011) Assessment of a Phytogenic Feed Additive Effect on Broiler Growth Performance, Nutrient Digestibility and Caecal Microflora Composition. Animal Feed Science Technology, 168, 223-231.

https://doi.org/10.1016/j.anifeedsci.2011.03.020

[16] Hong, J., Steiner, C.T., Aufy, A. and Lien, T.F. (2012) Effects of Supplemental Essential Oil on Growth Performance, Lipid Metabolites and Immunity, Intestinal Characteristics, Microbiota and Carcass Traits in Broilers. Livestock Science, 137, 219-225. https://doi.org/10.1016/j.livsci.2011.12.008

[17] Ahmed, A.R., Mangaiyarkarasi, U.S., Shahid, N., Rahmanullah, S. and Zahra, Y. (2013) Effect of Black Tea Extract (Polyphenols) on Performance of Broilers. International Journal of Advanced Research, 1, 563-566.

[18] Gowda, S.K., Verma, S.V.S., Elangovan, A.V. and Singh, A.D. (1998) Neem (Azadirachta indica) Kernel Meal in the Diet of White Leghorn Layer. British Poultry Science, 39, 648-652. https://www.ncbi.nlm.nih.gov https://doi.org/10.1080/00071669888520

[19] Ganong, W.F. (1999) Review of Medicinal Physiology. 19th Edition, Appleton and Lange, Stanford, 353.

[20] Al-Kassie, G.A.M. (2009) Influence of Two Plant Extracts Derived from Thyme and 
Cinnamon on Broiler Performance. Pakistan Vetenary Journal, 29, 169-173.

[21] Hashemipour, H., Kermanshahi, H., Golian, A. and Veldkamp, T. (2013) Effect of Thymol and Carvacrol Feed Supplementation on Performance, Antioxidant Enzyme Activities, Fatty Acid Composition, Digestive Enzyme Activities, and Immune Response in Broiler Chickens. Poultry Science, 92, 2059-2069. https://doi.org/10.3382/ps.2012-02685

[22] Vivian, U.O.O., Ndofor-Foleng, H.M., Olorunleke, S.O. and Uguru, J.O. (2015) Evaluation of Growth Performance, Haematological and Serum Biochemical Response of Broiler Chickens to Aqueous Extract of Ginger and Garlic. Journal of Agricultural Sciences, 7, 167-173. https://doi.org/10.5539/jas.v7n4p167

[23] Gerardo, M.Z., Lorenzo, A.D.M., Michael, E.H. and Ramón, S.V. (2017) Performance, Blood Parameters, and Carcass Yield of Broiler Chickens Supplemented with Mexican Oregano Oil. Brazilian Journal of Animal Science, 46, 515-520. https://doi.org/10.1590/s1806-92902017000600006

[24] Toghyani, M., Toghyani, M., Mohammadrezaei, M., Gheisari, A., Tabeidian, S.A. and Ghalamkari, G. (2011) Effect of Cocoa and Thyme Powder Alone or in Combination on Humoral Immunity and Serum, Biochemical Metabolites of Broiler Chicks. The Proceedings of the 2nd International Conference on Agricultural and Animal Science, Singapore, 25-27 November 2011, Vol. 22, 114-118.

[25] Ghazalah, A.A. and Ali, A.M. (2008) Rosemary Leaves as a Dietary Supplement for Growth in Broiler Chickens. International Journal of Poultry Science, 7, 234-239. https://doi.org/10.3923/ijps.2008.234.239

[26] Zhang, G.F., Yang, Z.B., Wang, Y., Yang, W.R., Ziang, S.Z. and Gai, G.S. (2009) Effects of Ginger Root (Zingiber officinale) Processed to Different Particle Sizes on Growth Performance, Antioxidant Status and Serum Metabolites of Broiler Chickens. Poultry Science, 88, 2159-2166. https://doi.org/10.3382/ps.2009-00165

[27] Fadlalla, M.T., Mohammed, B.H. and Bakhiet, A.O. (2010) Effect of Feeding Garlic on the Performance and Immunity of Broilers. Asian Journal Poultry Science, 4, 182-189. https://doi.org/10.3923/ajpsaj.2010.182.189

[28] Mansoub, N.H. and Myandoab, M.P. (2011) The Effects of Different Levels of Thyme on Performance, Carcass Traits, Blood Parameters of Broilers. Annals of Biological Research, 2, 379-385. https://doi.org/10.3923/rjpscience.2011.18.21

[29] El-Deek, A.A., Al-Harthi, M.A., Osman, M., Al-Jassas, F. and Nassar, R.(2012) Effect of Different Levels of Green Tea (Camellia sinensis) as a Substitute for Oxytetracycline as a Growth Promoter in Broilers Diets Containing Two Crude Protein Levels. Archiv fur Geflugelkunde, 76, 88-98.

[30] Gálik, B., Wilkanowska, A., Bíro, D., Rolinec, M., Šimko, M., Juráček, M., Herkel, R. and Maiorano, G. (2015) Effect of a Phytogenic Additive on Blood Serum Indicator Levels and Fatty Acids Profile in Fattening Turkeys Meat. Journal of Central European Agriculture, 16, 383-398. https://doi.org/10.5513/JCEA01/16.4.1642

[31] Saleh, A.A. (2014) Nigella Seed Oil as Alternative to Avilamycin Antibiotic in Broiler Chicken Diets. South African Journal of Animal Science, 44, 254-261. https://doi.org/10.4314/sajas.v44i3.7

[32] Gulec, A.K., Danabas, D., Ural, M., Seker, E., Arslan, A. and Serdar, O. (2013) Effect of Mixed Use of Thyme and Fennel Oils on Biochemical Properties and Electrolytes in Rainbow Trout as a Response to Yersinia ruckeri Infection. Acta Veterinaria Brno, 82, 297-302. https://doi.org/10.2754/avb201382030297

[33] Róbert, H., Branislav, G.B., Daniel, R., Michal, S., Milan, J., Miroslav, A. and He- 
nrieta, H.O. (2016) The Effect of Essential Plant Oils on Mineral Composition of Egg Mass and Blood Parameters of Laying Hens. Journal of Central European Agriculture, 17, 1150-1167. https://doi.org/10.5513/JCEA01/17.4.1824

[34] Rafiee, A., Rahimian, Y., Zamani, F. and Asgarian, F. (2013) Effect of Use Ginger (Zingiber officinale) and Thymus (Thymus vulgaris) Extract on Performance and Some Hematological Parameters on Broiler Chicks. Scientia Agricola, 4, 20-25.

[35] Manafi, M., Hedayati, M. and Yari, M. (2014) Aflatoxicosis and Herbal Detoxification: The Effectiveness of Thyme Essence on Performance Parameters and Antibody Titers of Commercial Broilers Fed Aflatoxin B1. Zoological Research, 4, 43-50.

[36] Štefan, F., Zita, F., Iveta, P. and Juraj, K. (2009) Effect of Cinnamomumzeylanicum Essential Oil on Antioxidative Status in Broiler Chickens. Acta Veterinaria Brno, 78, 411-417. https://doi.org/10.2754/avb200978030411

[37] Zeng, Z.K., Zhang, S., Wang, H.L. and Piao, X.S. (2015) Essential Oil and Aromatic Plants as Feed Additives in Non-Ruminant Nutrition: A Review. Journal of Animal Science and Biotechnology, 6, Article No. 7. https://doi.org/10.1186/s40104-015-0004-5

[38] Jamroz, D., Wertelecki, T., Houszka, M. and Kamel, C. (2006) Influence of Diet Type on the Inclusion of Plant Origin Active Substance on Morphological and Histochemical Characteristics of the Stomach and Jejunum Walls in Chicken. Journal of Animal Physiology and Animal Nutrition, 90, 255-268. https://doi.org/10.1111/j.1439-0396.2005.00603.x

[39] Khattak, F., Ronchi, A., Castelli, P. and Sparks, N. (2014) Effects of Natural Blend of Essential Oil on Growth Performance, Blood Biochemistry, Cecal Morphology, and Carcass Quality of Broiler Chickens. Poultry Science, 93, 132-137. https://doi.org/10.3382/ps.2013-03387

[40] Rahimi, S., Teymouri Zadeh, Z., KarimiTorshizi, M.A., Omidbaigi, R. and Rokni, H. (2011) Effect of the Three Herbal Extracts on Growth Performance, Immune System, Blood Factors and Intestinal Selected Bacterial Population in Broiler Chickens. Journal of Agricultural Science and Technology, 13, 527-539.

[41] Amera, S.A., Nahed, S.S., Tamer, S.A. and Emad, W.G. (2013) The Effects of Rosemary (Rosemarinus officinalis) and Garlic (Allium sativum) Essential Oils on Performance, Hematological, Biochemical and Immunological Parameters of Broiler Chickens. British Journal of Poultry Science, 2, 16-24.

[42] EL-Faham, A.I., Nematallah, G.M.A. and Hayam, M.A.A. (2014) Effect of Using Some Natural Feed Additives to Substitute Antibiotic Growth Promoters on Performance and Blood Parameters of Broilers. Egyptian Poultry Science, 34, 735-750. 